Research Article

\title{
Improving Oil Supply Security: Using a Risk Optimization Model to China and India
}

\author{
Ming Qi $(\mathbb{D}$, Danyang Shi, Congcong Li, Jialu Wu, and Pei Wang \\ School of Economics and Management, China University of Petroleum, Beijing, China \\ Correspondence should be addressed to Ming Qi; qiming@cup.edu.cn and Pei Wang; peggie_wang@126.com
}

Received 26 February 2021; Revised 19 April 2021; Accepted 27 May 2021; Published 9 June 2021

Academic Editor: Chun Wei

Copyright ( 2021 Ming Qi et al. This is an open access article distributed under the Creative Commons Attribution License, which permits unrestricted use, distribution, and reproduction in any medium, provided the original work is properly cited.

\begin{abstract}
In this paper, a risk optimization model is proposed to minimize the oil supply risk from the perspective of diversification. The results show that there is large room for both China and India to improve the oil supply security. China should reduce oil imports from Saudi Arabia and Russia while increasing oil imports from the United States and Kazakhstan. India should import more oil from America and Russia while substantially reducing imports from Iraq and Saudi Arabia. In terms of the regional analysis, the Middle East plays a crucial role in the oil import strategies. They account for almost half of the total oil imports to China and India. African countries provide an alternative choice to diversify their energy supply risks. Based on forecasts of oil demand, we investigate the optimal oil import strategies for both countries until 2030 and 2040. China's imports from the United States and Kazakhstan are forecasted to increase by more than ten times by 2030. India should import four times as much oil from the United States as it does now and import 10 times more crude oil from Russia. Africa and North America will play a more important role in India's oil supply security.
\end{abstract}

\section{Introduction}

Over the past two decades, the rapid economic growth of emerging Asian countries has greatly stimulated the demand for crude oil. A secure and stable oil supply plays an essential role in promoting continuous future economic growth. The security of oil supply is getting more and more attention from major importing countries, such as China and India. Von Hippel et al. comprehensively analyze the concepts of Energy Security and explain the reasons why oil supply has been the focus of energy security [1]. They defined the central tenets of energy security policy as "(1) reduction of threats of oil supply and (2) operating in a mode of crisis management." According to IEA, China and India were the world's largest importers of crude oil. China had imported even more crude oil than other Asia-Pacific countries. China and India are forecasting to import more crude oil than the European Union. Moreover, the crude oil import dependencies of China and India keep increasing and are expected to reach close to $80 \%$ in 2040 , which makes the imports play a significant role in the energy security for both China and
India. Figure 1 illustrates the annual oil consumption of China and India during the period from 1993 through 2040. According to the "World Energy Outlook" by the IEA, the oil demand of China and India is forecasted to hit $15600 \mathrm{tb} / \mathrm{d}$ (thousand barrels per day) and $7500 \mathrm{tb} / \mathrm{d}$, respectively, by 2030 [2]. The increased oil demand of these two emerging countries will contribute to an increase in global oil demand by almost 80 percent by 2030 . On the contrary, China and India will reach peak oil production by 2020 and 2025, respectively. As a consequence, the external oil dependencies of China and India keep increasing, as shown in Figure 2. The IEA forecasts that the external oil dependency rates of China and India will reach $79.49 \%$ and $89.33 \%$, respectively, by 2030 , and hit $80.65 \%$ and $91.89 \%$ by 2040 . Kraljic suggests that purchasing must be moderated by supply management consideration to cope with resource scarcity and to avoid supply interruptions [3]. This argument stems from corporate strategy consideration but also applies to resource supply management considerations. Both China and India are seeking strategies to ensure a continuous and stable oil supply from exporting countries. 


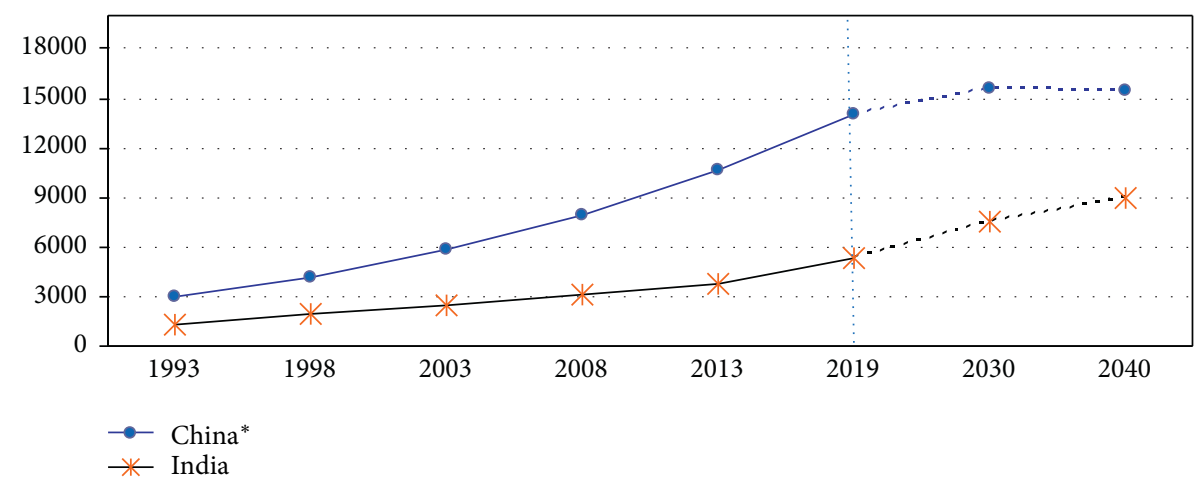

Figure 1: Annual oil consumption of China and India. Source: "BP Statistics (2020)" and IEA "World Energy Outlook (2019).” The dashed lines stand for the forecast values (unit: thousand barrels daily).

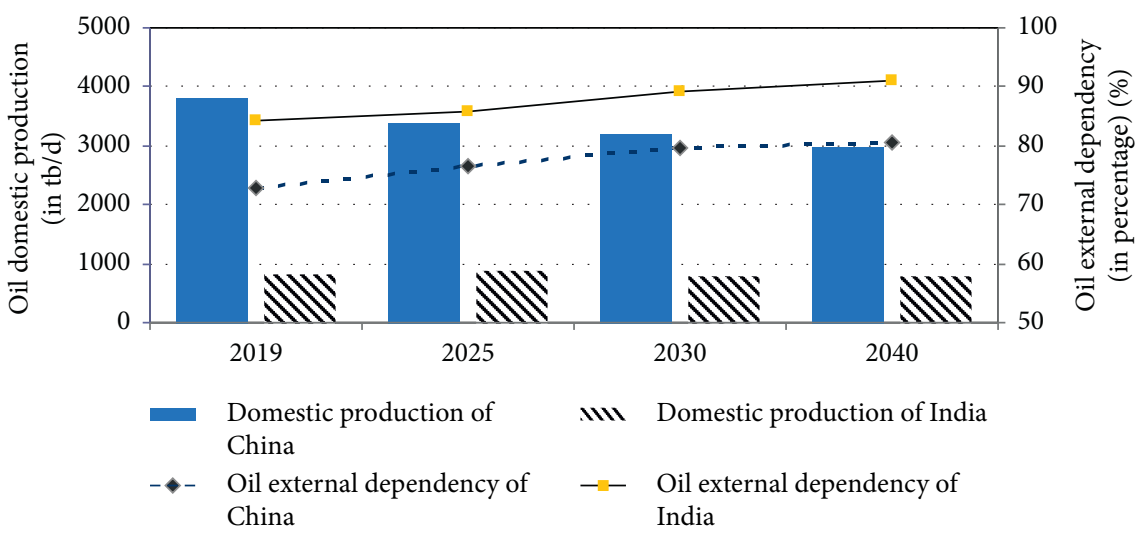

FIGURE 2: Oil production and external dependency of China and India. Source: BP Statistics (2020).

Refining capacity is another important constraint to ensure a stable oil supply. In response to the continuously rising demand and increasing supply deficit, China has made efforts to improve energy security by employing various methods, such as pipeline connection with central Asia countries and seeking new oil suppliers. (However, Leung argues that the pipeline through China, Russia, and Middle Asia is less effective than assumed. China's oil imports through the pipeline are still a long way off in the future [4]). Similarly, India is ramping up efforts to diversify its oil sources by increasing imports from Latin American and Africa. The refining capacities of China and India until 2040 are shown in Figure 3. Oil imports should satisfy refinery capacity, both in quantity and quality $[5,6]$. China and India need to expand their domestic refinery capacities to meet the demand for increasing petroleum products and crude oil imports [7, 8]. According to forecasts by the IEA, cumulative investments into China's refining industry will amount to $\$ 210$ billion by 2035 . India is expected to invest $\$ 3$ billion to expand and update its domestic oil refining industry. The total investment into the refining sector by China and India will account for almost $35 \%$ of global refining investment between 2011 and 2035 [9]. Figure 3 illustrates the oil refining capacities of our sample countries.

In this paper, an optimization model is proposed to investigate oil supply risk quantitatively from the perspective of the diversification of oil imports. Based on the optimization model, we propose the optimal strategies and provide some policy suggestions for both China and India to improve their oil supply security. The first contribution of this paper is to propose a novel optimization model to investigate oil supply security from the perspective of risk diversification. Since the US has become a crude oil supplier in the global market, traditional importing countries, such as China and India, have more choices of suppliers. The cost will be an important factor in determining the oil imports policy. Therefore, the second contribution of this paper is to involve price in the model in order to reflect the import cost and make the model more realistic for policymakers. The structure of this paper is as follows. In Section 2, we overview the existing literature on the concept of energy security. In Section 3, the methodology is outlined to optimize the oil import strategies for China and India. Section 4 provides the source of data and investigates the current import strategy. In Section 5, the results of different scenarios and further discussions on policy recommendations are presented. Finally, we conclude the paper by summarizing the main findings and policy suggestions.

\section{Literature Review}

The issue of crude oil imports has been a topic of considerable concern to academic researchers. A large body of indices has been developed to evaluate the energy security of 


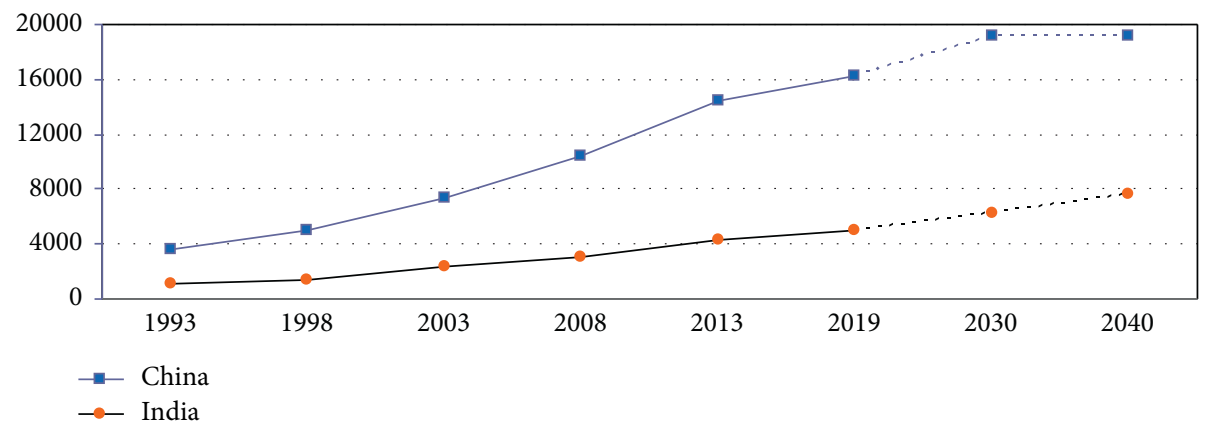

Figure 3: The refining capacity. Source: "BP Statistics (2020)" and IEA “World Energy Outlook (2019).” The dashed lines stand for the forecast values. Unit: thousand barrels daily.

different countries and regions, such as HerfindahlHirshman Index (HHI), Principle Component Technique (PCT), Security of Supply (SOS), Energy Security Price Index (ESPI), Energy Security Physical Availability Index (ESPAI), Sustainable Energy Security (SES) index, Integrated Assessment Models (IAMs), Aggregated Energy Security Performance Indicator (AESPI), and Ecological network analysis (ENA) [10-24]. Vivoda proposes a novel "energy security assessment instrument," which involves eleven broad energy dimensions to assess the energy security in the Asian-Pacific region [6]. The share of oil exports to annul oil production for an oil-supplying country is also of significance to the diversification effect of oil supply security [25]. Lesbirel and Sun have shown that the underlying trend towards more diversification in some Asian-Pacific countries has enhanced oil import security in the region [26]. The situation of China's energy security has deteriorated because of demand growth, domestic resources restriction, energy technological obstacles and the difficulty in obtaining resources [27-29]. China's oil import risks have kept rising and face multiple potential threats from each stage of the oil import supply chain, among which the threat from external dependence has become the biggest challenge [30]. Many studies have investigated oil supply risks quantitatively based on some risk assessment models, such as the DEA-like model and system dynamic model [6, 30-34]. Other studies assess oil risk by designing frameworks with risk factors or risk assessment indexes [22, 35, 36]. Geng and Ji construct a multidimensional indicator to measure China's energy supply risk quantitatively [29]. The results indicate that a ten percent increase in Oil Import Risk (OIR) will make the oil imports increase to 2237 million Yuan. However, China has expanded the oil trade partners by importing more from suppliers with high potential exports. By the Sino-Russian oil cooperation study, China's oil import sources tend to be diverse, and Russia plays an important role in balancing China's external oil supply and reducing its concentration [24]. Previous studies suggest that China should increase oil imports from countries and regions with low country risks. However, sourcing from more distant West African producers, Middle East exporters can capture an inframarginal or locational rent from Asian countries [37]. In countries along the "One Belt and One Road," China's oil imports from Iraq and Qatar were more vulnerable to supply risks, and oil imports from other oil-producing countries in the Middle East were less affected [38].

According to more detailed studies, the southwest and eastern coastal areas of China are vulnerable to potential oil supply disruptions, while northwest China enjoys high supply security [35]. As another promising emerging market, India has shown rapid economic growth and soaring oil demand. The level of Availability and Efficiency increases India's Sustainable Energy Security (SES), while the level of Acceptability and Affordability decreases India's SES [3]. With the growing demand for crude oil, Pode forecasts the increase of India's annual oil demand in the next quarter-century to be approximately $2.9 \%$ [39]. Although India has shown a higher oil imports diversification level than China, EU, and US, it needs more diversified oil suppliers to meet its oil demand in the future [21, 30]. Sharma and Kondepati discuss the current policy measures of India and argue that policy responses should contribute to coping with an emergency case, such as oil shock $[40,41]$.

\section{Methodology}

In this section, a risk measure from the perspective of the diversification of oil import sources is presented since the composition of import suppliers plays a significant role in determining the oil supply risk $[6,12,14]$. A well-diversified oil supply portfolio provides an importing country with greater resilience against supply shocks. In other words, an importing country is capable of withstanding the underlying risk of a regional oil supply shortage, which may be the result of a supply disruption or other unpredictable shocks. Following Cohen et al. and Ming et al., the risk measure is defined as the product of political risks of the supplying countries, oil import price, oil import quantity, and the Herfindahl-Hirschman Index (HHI) [14, 42, 43]. The risk measure is minimized to obtain the optimal oil imports for each supplying country. The objective function is subject to the consumption and refinery constraints, which make the crude oil supply satisfies the oil consumption and refining capacity of the importing country simultaneously. 


$$
\begin{aligned}
& \min _{q_{i}} Z=\sum_{i \in I}\left[r_{i} \cdot \sum_{i \in I}\left(\frac{q_{i}}{Q_{i}}\right)^{2} \cdot P_{i}\left(q_{i}\right) \cdot \frac{q_{i}}{Q e_{i}}\right], \\
& \text { s.t. } \frac{\sum_{i \in I} q_{i}}{w_{j}} \geq D-\operatorname{Pr}-\text { consumption, } \\
& \frac{\sum_{i \in I} q_{i}}{w} \leq R \quad \text { refinery capacity, } \\
& 0 \leq q_{i} \leq \text { Qei } \forall i \text { - rationality, }
\end{aligned}
$$

where $Z$ denotes the oil import risk measure, $P_{i}\left(q_{i}\right)$ is the oil import costs, $Q_{j}$ is the total crude consumption of country $j$, $q_{i}$ stands for oil imports from the exporting country I, $Q e_{i}$ denotes the crude oil exports of country $i$. Following the method of Le Coq, we use the Herfindahl-Hirschman index (HHI), measured as $\sum_{i \in I}\left(q_{i} / Q_{i}\right)^{2}$, to evaluate the diversification of oil import sources. As mentioned in Holz et al., the price should be determined by the import quantity. Therefore, the reserve demand function of $P_{i}\left(q_{i}\right)$ is used to denote the crude oil import price from country $i$. D, $\operatorname{Pr}, R$ stand for the domestic demand, production, and refinery capacity for each country respectively. $\left(q_{i} / Q e_{i}\right)$ stands for the ratio of oil trade between countries $i$ and $j$ to annual oil production of country $i$. Wan et al. note that considering the diversification strategy of an exporting country is also necessary [25]. Oil suppliers adopt the same strategic attitude about building a diversified portfolio of target countries. An oil supplier prefers to have more diversified target importers to reduce the trading risk. On the other hand, if an oil-consuming country imports a large proportion of oil from an individual supplier, it may suffer a high risk of a supply shortage as a result of the oil supply disruption of the individual supplier. In other words, if the oil exports to country $j$ account for a smaller proportion of the total production of the supplier, then the importing country $j$ is less likely to be influenced by a possible oil supply reduction of country $i$. The country risk index, denoted as $r_{i}$, is used to capture a country's current political situation. The International Country Risk Guide (ICRG) rating, which is produced by the Political Risk Service (PRS) Group, is the most widely accepted country risk measure. However, the ICRG political risk index is based on a $(0,100)$ scale, where a high score indicates low country risk. To make the risk index compatible with our model, the country risk index $r_{i}$ is instead defined as follows:

$$
r_{i}=100-I C R G_{i}
$$

where $I C R G_{i}$ is the political risk rating from PRS international country risk guide for each oil-exporting country $i$.
After transformation, $r_{i}$ remains on the $(0,100)$ scale, but high values are associated with the high risk of country $i$. Thus, the product of $\left[r_{i}\left(q_{i} / Q e_{i}\right)\right]$ can be explained as the Sustainable Availability Index (SAI) of oil, which is in line with Fang et al. [23]. A higher value of SAI implies that the exporting country $i$ bears a higher risk in the world oil market or that the imports from country $i$ are more vulnerable to the production shock. According to the demand constrain of equation (1), the sum of domestic oil production and external imports of each oil-importing country should meet the consumption demand. In this model, the top twenty suppliers of each country are analyzed. (Minor suppliers are excluded in the analysis because a low oil trading volume normally implies a low potential to raise oil imports considerably in a short time period. Many factors can determine oil trading between countries, such as transport distances, freight costs, and political relationships [6]. Consequently, oil-importing countries have little room to improve their energy strategies with minor suppliers. On the contrary, from the perspective of geopolitics, the volume of oil imports also reflects the bilateral diplomatic relationship between an exporting country and an importing country. A high volume of oil imports is normally a result of a stable bilateral relationship.). In 2019, the crude oil imports from the top twenty supplying countries accounted for 94.96\% and $96.19 \%$ of total oil imports to China and India, respectively. The amount paid to top twenty supplying countries accounted for $94.88 \%$ and $96.13 \%$ of total oil import payments of China and India, respectively. It is defined as the information set of top twenty supplying countries.

This observation result is representative enough to outline the crude import strategies of China and India. The common supply risks of China and India are minimized. Here, we use $w_{j}$ to denote the percentage of oil imports from the top ten supplying countries to the total oil imports of country $j$. On the other hand, the sum of domestic oil production and external imports of each oil-importing country should satisfy its own refinery capacity, as shown in equation (1). Since there are equalities together with inequalities in our nonlinear program, a mixed complementarity problem (MCP) model, which is programmed in GAMS, is appropriate to solve the problem. Therefore, we use a standard algorithm for MCP and the PATH solver for the investigation. The objective function is assumed to be concave, and the constraints are linear, referring to the GASMOD by Holz et al. [44]. The model can be solved by the Lagrange formula as follows:

$$
L=\sum_{i \in I}\left[r_{i} \cdot \sum_{i \in I}\left(\frac{q_{i}}{Q_{j}}\right)^{2} \cdot P_{i}\left(q_{i}\right) \cdot \frac{q_{i}}{Q e_{i}}\right]+\lambda^{D}\left((D-P)-\frac{\sum_{i \in I} q_{i}}{w}\right)+\lambda^{R}\left(\frac{\sum_{i \in I} q_{i}}{w}-R\right)+\lambda_{i}\left(q_{i}-Q e_{i}\right),
$$


$\lambda^{D}, \lambda^{R}$, and $\lambda_{i}$ represent the Lagrange multiplier for constraint (1). Karush-Kuhn-Tucker (KKT) conditions are shown in equation (4) in order to solve the optimal quantity $q_{i}$ :

$$
\begin{aligned}
& \sum_{i \in I}\left[\frac{r_{i}}{Q_{j}^{2} \mathrm{Qe} e_{i}} \cdot \frac{\left.\partial\left[P_{i}\left(q_{i}\right) \cdot q_{i}^{3}\right]\right]}{\partial q_{i}}\right]+\frac{\lambda^{D}+\lambda^{R}-\lambda_{i}}{w} \geq 0 \perp q_{i} \geq 0 \\
& \Rightarrow \frac{r_{i} \cdot q_{i}^{2}}{Q^{2} \cdot Q e_{i}} \cdot \sum_{i \in \mathrm{I}}\left[\frac{\partial\left[\mathrm{P}_{\mathrm{i}}\left(q_{i}\right)\right]}{\partial q_{i}} \cdot q_{i}+3 \mathrm{P}_{\mathrm{i}}\left(q_{i}\right)\right]+\frac{\lambda^{D}+\lambda^{R}-\lambda_{i}}{\mathrm{w}} \geq 0 \perp q_{i} \geq 0 \\
& \Rightarrow \frac{r_{i} \cdot q_{i}^{2}}{Q^{2} \cdot Q e_{i}} \cdot \sum_{i \in I}\left[\frac{\partial P_{i}\left(q_{i}\right)}{\partial q_{i}} \cdot \frac{P_{i}\left(q_{i}\right)}{P_{i}\left(q_{i}\right)} \cdot \frac{\partial Q}{\partial \mathrm{Q}} \cdot \frac{Q}{\mathrm{Q}} \cdot q_{i}+3 P_{i}\left(q_{i}\right)\right]+\frac{\lambda^{D}+\lambda^{R}-\lambda_{i}}{w} \geq 0 \perp q_{i} \geq 0,
\end{aligned}
$$

$\sigma=\left(\partial \mathrm{Q} / \partial P_{i}\left(q_{i}\right)\right) \cdot\left(P_{i}\left(q_{i}\right) / Q\right)$ denotes the price elasticity of crude oil imports, and $\theta_{i}=\left(q_{i} / Q e_{i}\right)$ is the proportion of oil imports from country $i$ to its total oil exportation. Salant and Sinn suggested that the world oil market be a Cournot noncooperative model. Al-Sultan also concluded that Nash-Cournot noncooperative model has more advantages to explain the world oil market more than the competitive model [45-47]. Therefore, we assume the Cournot competition in the world oil market and no player must have an incentive to move unilaterally. (Holz et al. considered the behavioral assumption of Cournot competition and argued that in a pure Cournot-Nash equilibrium, the conjectured variation of the other players must be zero [44].). Hence,

$$
\alpha=\frac{\partial Q}{\partial q_{i}}=1 .
$$

Then, equation (4) can be expressed as follows:

$$
\frac{r_{i} \cdot q_{i}^{2} P_{i}\left(q_{i}\right)}{Q_{j}^{2} \cdot Q e_{i}} \cdot \sum_{i \in I}\left[\frac{1}{\sigma} \cdot \theta_{i} \cdot \alpha+3\right]+\frac{\lambda^{D}+\lambda^{R}-\lambda_{i}}{w} \geq 0 \perp q_{i} \geq 0 .
$$

$\sigma$ denotes the price elasticity of demand for crude oil. Following Cooper [48], a multiple regression model is used to estimate both the short-run and long-run elasticities of demand for crude in 23 countries. If we use $\mathrm{D}_{t L}$ and $\mathrm{D}_{t S}$ to denote the long-run and short-run demand for oil in year $t$, $P_{t}$ and $Y_{t}$ stand for the real price of oil and real GDP per capita in year $t$, and the long-run demand function for crude oil can be expressed as follows:

$$
D_{t L}=a \cdot P_{t}^{b} \cdot Y_{t}^{c} \cdot e_{t},
$$

where $b$ denotes the long-run price elasticity of oil demand, and the gradual adjustment process of oil demand can be expressed as follows:

$$
\frac{\mathrm{D}_{t L}}{\mathrm{D}_{t S}}=\left[\frac{\mathrm{D}_{t L}}{\mathrm{D}_{t-1, S}}\right]^{d}
$$

Then, $\mathrm{D}_{t L}$ can be solved as follows:

$$
\mathrm{D}_{t L}=\left[\frac{\mathrm{D}_{t S}}{\left(\mathrm{D}_{t-1, S}\right)^{d}}\right]^{(1 /(1-d))} .
$$

Then, we get

$$
\begin{aligned}
a \cdot P_{t}^{b} \cdot Y_{t}^{c} \cdot e_{t} & =\left[\frac{\mathrm{D}_{t S}}{\left(\mathrm{D}_{t-1, S}\right)^{d}}\right]^{(1 /(1-d))} \\
& \Rightarrow \mathrm{D}_{t S}=a^{(1-d)} \cdot P_{t}^{b(1-d)} \cdot Y_{t}^{c(1-d)} \cdot \mathrm{D}_{t-1, S}^{d} \cdot e_{t}^{(1-d)} .
\end{aligned}
$$

Taking logarithm to (10),

$$
\begin{aligned}
\log \mathrm{D}_{t S}= & (1-d) \log a+b(1-d) \log P_{t}+c(1-d) \log Y_{t} \\
& +d \log \mathrm{D}_{t-1, S}+(1-d) \log e_{t} .
\end{aligned}
$$

Then, we get the regression model for $\log \mathrm{D}_{t S}$ as follows:

$$
\log \mathrm{D}_{t S}=\alpha+\beta_{1} \log P_{t}+\beta_{2} \log Y_{t}+\beta_{3} \log \mathrm{D}_{t-1, S}+\varepsilon_{t} .
$$

Following equation (12), we use the data of GDP, population, and crude oil price data to get the regression results as follows:

China: $\log \mathrm{D}_{t S}=-1.106+0.014 \log P_{t}+0.066 \log Y_{t}+0.823 \mathrm{D}_{t-1, S}$,

India: $\log \mathrm{D}_{t S}=-2.967-0.038 \log P_{t}+0.087 \log Y_{t}+0.84 \mathrm{D}_{t-1, S}$.

The results indicate that the short-run price elasticity of crude oil demand for China is 0.014 and the long-run price elasticity is $(0.014 /(1-0.823))=0.079$. It implies that due to the ever-increasing oil imports and demand rigidity, both short- and long-run oil demand increase with the rising crude oil prices. This result is obviously different from other countries but in line with the results of Copper and Gang $[48,49]$. On the contrary, the short-run price elasticity of crude oil demand for India is -0.038 and the long-run price elasticity is $-(0.038 /(1-0.84))=-0.238$. The short-run and long-run price elasticities of crude oil demand for India are negative. It implies that both short- and long-run oil demand decrease with the rising crude oil prices. This result is consistent with the results of most countries [48]. 


\section{Data and the Current Situation}

4.1. Data Description. A variety of data is used as input parameters for the model. The statistics of China's top twenty oil import sources come from the General Administration of Customs of the People's Republic of China. India's oil imports data is collected from UN Comtrade Database. The forecasted crude oil consumption data for China and India comes from BP statistics (2019) and World Energy Outlook (2019) by the IEA $[2,50]$. The forecasted oil production of China and India is based on World Energy Outlook (2019) [2]. The refining capacities are collected from World Energy Outlook (2019) [2]. The crude oil production is collected from World Energy Outlook (2019) under the New Policies Scenario and IEA website. We use the country composite risk rating and forecasts from the ICRG report. It is produced by the PPRS Group and is widely used in previous studies $[10,12,14]$.

4.2. Current Imports' Strategy Analysis. Before presenting the optimal strategies, we need to understand the current oil supply situation of China and India in 2019. The most common feature is the heavy reliance of both countries on oil imports from the Middle East. Figure 4 illustrates China's crude oil imports and the decomposition of risk measures by supplying country. It shows that Saudi Arabia is the largest crude oil supplier to China, followed by Russia and Iraq. About half of China's crude oil imports (46\%) come from the Middle East. The distribution of risk measures by country is uneven. The highest oil supply risk comes from Angola, followed by Congo, Gabon, and South Sudan. Furthermore, the top four risky suppliers contribute to 50 percent of total risk measures. All of these statistics imply that there is plenty of room for China to improve its oil imports security.

India's crude oil imports and the decomposition of risk measures by country are illustrated in Figure 5. Iraq ranks first among all suppliers, followed by Saudi Arabia, United Arab Emirates (UAE), Nigeria, and Venezuela. Middle Eastern countries contribute approximately $64 \%$ of the total oil imports. Despite some energy cooperation, Russian still accounts for a small proportion of India's oil imports portfolio. Notably, in terms of supply security, the risk measure $(Z)$ of Turkey hits 1871.87 in 2019. This high measure can be attributed to two facts. First, Turkey has the highest oil price among all of the suppliers. Second, the political risk of Turkey is also very high, which is the fourthhighest among all suppliers.

4.3. Optimization Results. In this section, we present the optimal strategies of China and India. The optimization forecasts for the period ending in 2030 and 2040 are proposed.

4.3.1. Optimal Strategies for 2019. Based on the model presented in Section 3, we obtain the optimal oil import strategies for China and India, respectively, as shown in Table 1 . The results indicate that India's optimal and current risks are lower than China's. There is still a big gap between the current and optimal risks for China and India. Therefore, there is huge room for both China and India to improve their oil supply securities.

The results also set forth the optimal strategy for each country to identify an optimal path to improve its energy security, as shown in Figure 6. Due to the high production level and low policy risk of the United States, the imports from the US in 2019 are considerably lower than their optimal level, which is in line with the optimal strategy in 2018 [42]. Only 1\% of China's crude oil imports are from the US under the influence of international relations. The situation leaves large room for China to improve the oil supply risk. However, the cross-country relationship makes the increase of international trade between two countries uncertain. On the other hand, China should reduce oil imports from Saudi Arabia, Angola, and Iraq by about half to diversify the high political risks of African and the Middle East countries. In addition, the shipment from Africa back to China is not a profitable trading strategy, which makes the increase of oil trade between China and African counties not easy [4]. China should also considerably reduce oil imports from Russia due to the increasing and high import proportion, as well as Russia's domestic risk. Finally, China should moderately raise crude oil imports from Kazakhstan and UAE, reduce oil imports from Brazil and Oman while keeping oil imports from Congo and Gabon stable.

Comparing the optimal and actual data, India imported too much crude oil from Iraq and Saudi Arabia. The oil imports from these two countries account for $43 \%$ of India's total oil imports in 2019, which makes India's oil supply security vulnerable. Once the two countries confront internal turmoil or crude oil supply shock, India will suffer considerable import risk. In particular, two oilfields of Saudi Aramco were attacked by UAVs in 2019, which increased the country's risk of Saudi Arabia. In addition, Nigeria, Venezuela, Mexico, and the UAE also import more crude oil than the optimal imports. (However, Dalei et al. pointed out that UAE remained relatively and significantly least preferred nation for India than other countries to import crude oil [51]). Therefore, it is optimal to transfer some crude oil imports from Saudi Arabia and Iraq to other countries in order to improve India's oil supply security. The actual quantity of crude oil imported by India from the United States in 2019 is far less than the optimal quantity. There are two possible reasons for this phenomenon. First, the political risk of the United States is the lowest among all Indian Importers. The low country risk of the United States provides a guarantee for the stability of India's crude oil supply. This result is in line with the analysis by Ren [52]. The United States has the highest crude oil production level, with an annual production of 746.7 million tons in 2019. Due to the high crude oil production in 2019, India is capable of improving more oil from Russia in order to diversify the oil supply risk. Furthermore, India's current imports from Kazakhstan, Algeria, Egypt, Qatar, and Brazil are about 2 million tons. All of these countries could become the target countries of India's crude oil import diversification due to 


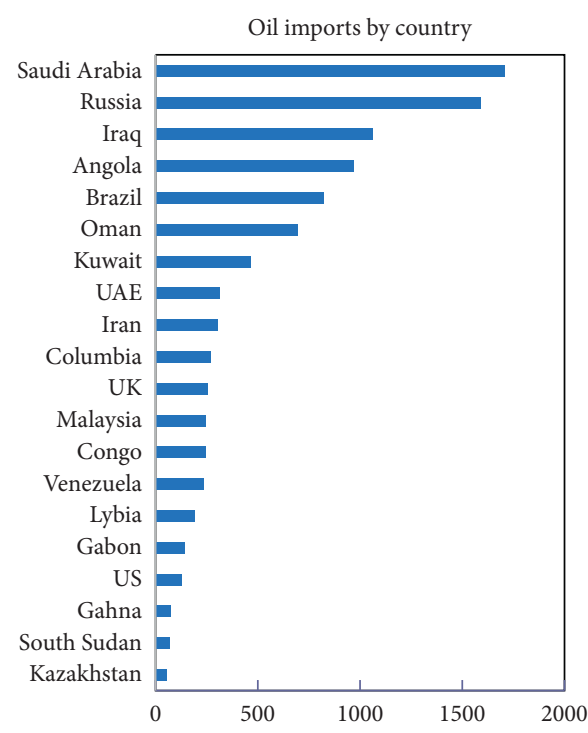

(a)

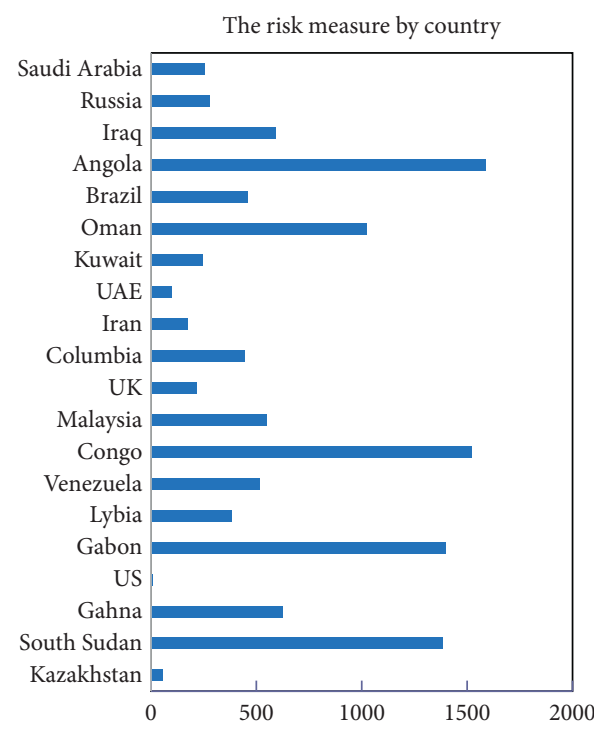

(b)

FIgURe 4: China's crude imports and the decomposition of the risk measure by country (2019). Unit: thousand barrels per day (tb/d). Source: General Administration of Customs of the People's Republic of China.

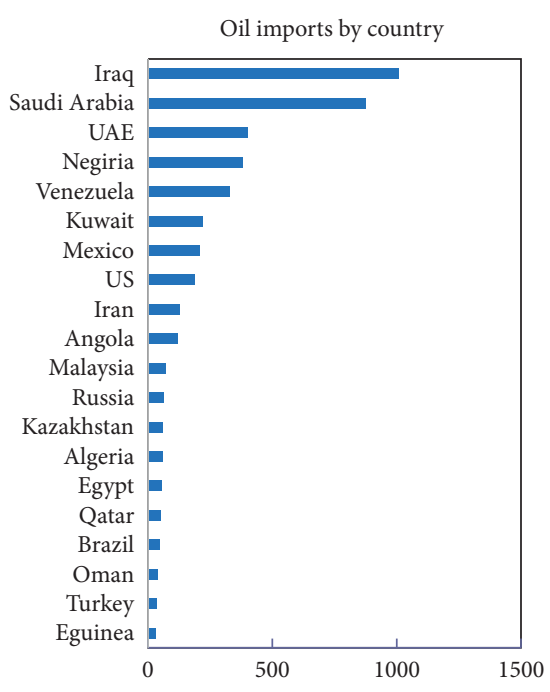

(a)

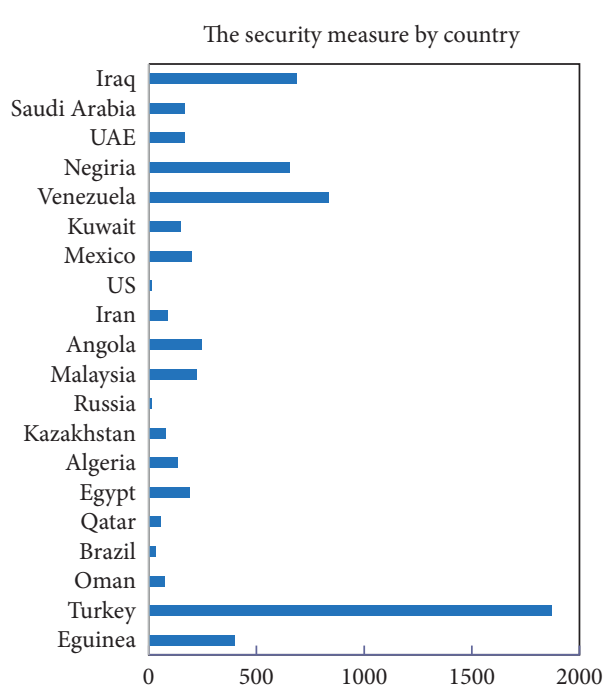

(b)

FiguRE 5: India's oil imports and the decomposition of the risk measure (Z) by country (2019). Source: Reuters. Unit: thousand barrels per day $(\mathrm{tb} / \mathrm{d})$.

TABLE 1: The optimal and current risk measures of China and India in 2019.

\begin{tabular}{lcc}
\hline & China & India \\
\hline Optimal & 9382 & 3562 \\
Current $^{*}$ & 11788 & 6262 \\
Difference $^{* *}$ & 2406 & 2700 \\
\hline
\end{tabular}

${ }^{*}$ Current denotes the risk measure $(Z)$ of each country in $2019 .{ }^{* *}$ Difference means (current-optimal).

the low crude oil price. Finally, the results indicate that the imports from Kuwait and Mexico are quite close to the optimal level.
The regional analysis is illustrated in Figure 7. A noticeable phenomenon is that the Middle East countries contribute 38 percent of oil imports for China and 43 percent of oil imports for India. Apparently, seeking a stable oil supply from the Middle East plays a crucial role in the oil import strategies. This finding is consistent with the view that the Middle East is expected to focus more on its fossil fuel exports to Asia and to increase oil sales to Asian countries dramatically $[53,54]$. Although the Middle East will remain the largest crude oil import region in the future, the proportion of crude oil import is proposed to be reduced. The forecast results in 2030 suggest that India's crude oil import proportion from North America should be increased 


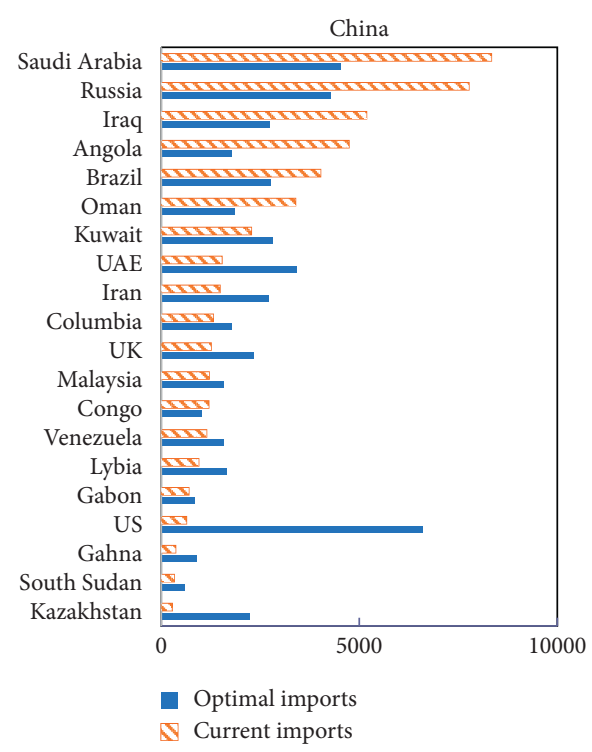

(a)

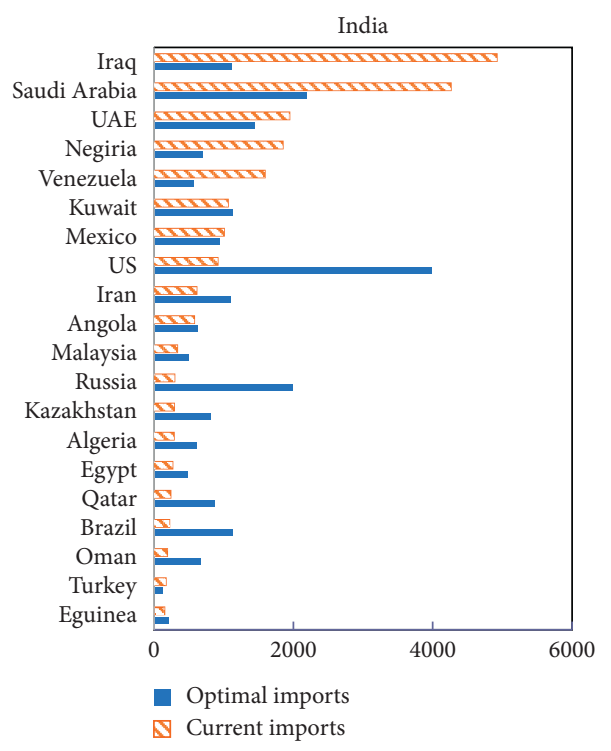

(b)

Figure 6: The optimal import strategies for China and India in 2019. Unit: thousand barrels per day (tb/d).

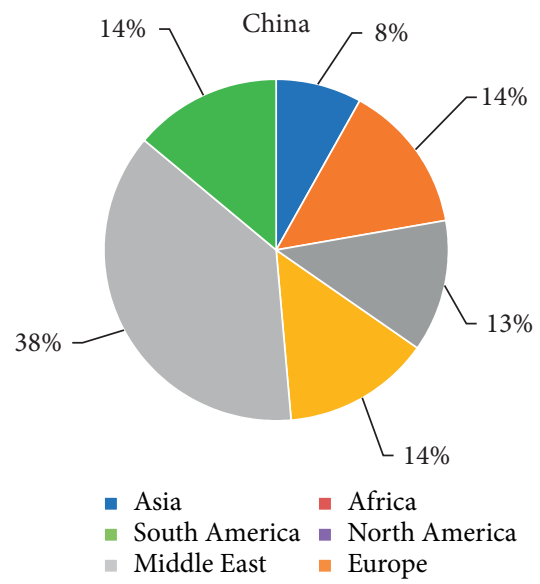

(a)

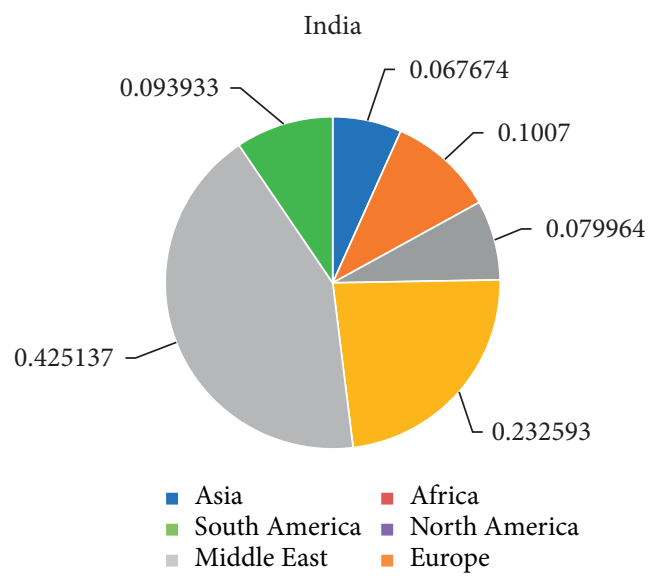

(b)

Figure 7: Optimal crude imports by region (2019).

from $9 \%$ to $26 \%$, and the proportion of African crude oil import should be increased to $21 \%$ in 2040 . On the contrary, Russia is an important and indispensable supplier to China. The oil imports from Russia and the Middle East to China will depend on the investment in the intercountry oil pipelines. Because of the relatively high country risk, the optimal strategy suggests lower crude oil imports from African countries. On the contrary, African countries provide an alternative choice for China and India to diversify their energy supply risks. Africa is the second-largest regional supplier for India, accounting for about $14 \%$ of total oil imports.

4.3.2. Strategic Perspectives for the Forecast Period. The scenario analysis provides us with an opportunity to estimate the future oil supply trend. Based on the forecasts of oil demand and production levels from IEA and BP statistics, the optimal oil import strategies for China and India during the forecast period are estimated, as shown in Table 2. China's oil supply risk will continue to rise as a result of increasing oil import dependence. The United States will be the largest crude supplier during our forecast period, followed by Saudi Arabia and Russia. This result is consistent with the prediction of China's optimal imports in 2025 and 2040 [42]. To meet the fast-growing oil demand in the future, China's crude oil imports from the US and Kazakhstan are forecasted to be 17 times and 10 times, respectively, to 2019 by 2030. The optimal strategy implies that the oil supply from UAE to China should be tripled by 2030. However, crude oil imports from Angola and Congo are forecasted to grow slowly. This can be attributed to the relatively high 
TABLE 2: The crude imports' forecasts until 2040 by country (units: thousands of tons).

\begin{tabular}{|c|c|c|c|c|c|c|c|}
\hline \multicolumn{8}{|c|}{ China } \\
\hline Rank & Country & 2030 & 2040 & Rank & Country & 2030 & 2040 \\
\hline 1 & Saudi Arabia & 6200 & 6319 & 11 & UK & 2357 & 2242 \\
\hline 2 & Russia & 5289 & 5077 & 12 & Malaysia & 1693 & 1413 \\
\hline 3 & Iraq & 3556 & 3792 & 13 & Congo & 500 & 500 \\
\hline 4 & Angola & 1897 & 1850 & 14 & Venezuela & 1664 & 2211 \\
\hline 5 & Brazil & 3722 & 4009 & 15 & Lybia & 1744 & 2046 \\
\hline 6 & Oman & 1894 & 1801 & 16 & Gabon & 500 & 500 \\
\hline 7 & Kuwait & 3476 & 3520 & 17 & US & 10557 & 10288 \\
\hline 8 & UAE & 4417 & 4616 & 18 & Ghana & 796 & 700 \\
\hline 9 & Iran & 3566 & 3767 & 19 & South Sudan & 840 & 698 \\
\hline 10 & Columbia & 1445 & 1145 & 20 & Kazakhstan & 2764 & 2857 \\
\hline \multicolumn{8}{|c|}{ India } \\
\hline Rank & Country & 2030 & 2040 & Rank & Country & 2030 & 2040 \\
\hline 1 & Iraq & 1484 & 1435 & 11 & Malaysia & 599 & 1961 \\
\hline 2 & Saudi Arabia & 2804 & 2804 & 12 & Russia & 2269 & 997 \\
\hline 3 & UAE & 1834 & 5098 & 13 & Kazakhstan & 1057 & 665 \\
\hline 4 & Nigeria & 838 & 1451 & 14 & Algeria & 722 & 411 \\
\hline 5 & Venezuela & 662 & 1250 & 15 & Egypt & 499 & 1284 \\
\hline 6 & Kuwait & 1416 & 1753 & 16 & Qatar & 1258 & 1553 \\
\hline 7 & Mexico & 1169 & 809 & 17 & Brazil & 1569 & 623 \\
\hline 8 & US & 5868 & 818 & 18 & Oman & 724 & 209 \\
\hline 9 & Iran & 1484 & 641 & 19 & Turkey & 242 & 177 \\
\hline 10 & Angola & 725 & 2604 & 20 & Guinea & 193 & 1304 \\
\hline
\end{tabular}

country risks and the forecasted slower production growth of both countries. Considering the peak crude oil production (According to forecasts by the IEA, the domestic oil production of China will reach the peak value of $4200 \mathrm{tb} / \mathrm{d}$ in 2015. Subsequently, production will decline gradually.), China should continue to diversify the crude oil import sources and explore the unconventional oil market to make up for future declining domestic production. In terms of the regional analysis, as shown in Table 3, the Middle East will maintain the dominant position in oil supply during the forecast period. The optimization results suggest almost half of the total oil supplies will come from the Persian Gulf countries. Therefore, a stable oil supply from the Middle East is very important for China to ensure its oil security. On the other hand, China should improve its oil refinery capacity to process heavy oil from the Middle East high-sulfur crude oil. North America is also a significant crude supplier to China. The US will contribute to more than 20 percent of China's oil imports during the forecast period. Besides, we find that the growth rate of crude oil imports from Kazakhstan is quite high. The Kazakhstan-China pipeline is an important crossborder oil pipeline for China. Our optimal strategy suggests that the crude oil imports from Russia will keep decreasing in 2030 and 2040, which can be explained by the effectiveness of China's pipeline with Russia. The loan-for-oil trade will considerably promote energy cooperation among China, Russia, and Kazakhstan.

India's total crude oil imports will reach 274.14 million tons by 2030 . Due to the less dependency on fossil fuel and reduced oil consumption, the total imports will be slightly reduced by 2040. The United States is forecasted to be the largest supplier by 2040 . Besides, the optimal crude oil imports from the Russia,
TABLE 3: The crude imports' forecasts until 2040 by region (units: thousands tons).

\begin{tabular}{|c|c|c|c|c|}
\hline \multicolumn{5}{|c|}{ China } \\
\hline & \multicolumn{2}{|c|}{2030} & \multicolumn{2}{|r|}{2040} \\
\hline Region & Amount & $\begin{array}{c}\text { Proportion } \\
(\%)\end{array}$ & Amount & $\begin{array}{c}\text { Proportion } \\
(\%)\end{array}$ \\
\hline Asia & 4456 & 8 & 4270 & 7 \\
\hline Africa & 6276 & 11 & 6293 & 11 \\
\hline $\begin{array}{l}\text { South } \\
\text { America }\end{array}$ & 6830 & 12 & 7365 & 12 \\
\hline $\begin{array}{l}\text { North } \\
\text { America }\end{array}$ & 10557 & 18 & 10288 & 17 \\
\hline Middle East & 23109 & 39 & 23815 & 40 \\
\hline Europe & 7646 & 13 & 7320 & 12 \\
\hline \multicolumn{5}{|c|}{ India } \\
\hline & \multicolumn{2}{|c|}{2030} & \multicolumn{2}{|r|}{2040} \\
\hline Region & Amount & $\begin{array}{c}\text { Proportion } \\
(\%)\end{array}$ & Amount & $\begin{array}{c}\text { Proportion } \\
(\%)\end{array}$ \\
\hline Asia & 1899 & 7 & 2803 & 10 \\
\hline Africa & 2477 & 9 & 5769 & 21 \\
\hline $\begin{array}{l}\text { South } \\
\text { America }\end{array}$ & 2231 & 8 & 1873 & 7 \\
\hline $\begin{array}{l}\text { North } \\
\text { America }\end{array}$ & 7037 & 26 & 1627 & 6 \\
\hline Middle East & 11502 & 42 & 14776 & 53 \\
\hline Europe & 2269 & 8 & 997 & 4 \\
\hline
\end{tabular}

Kazakhstan, Qatar, Brazil, and Oman are predicted to achieve about five to eight times the current imports. Notably, India's total crude oil imports will decline by 2040 . The imports from the United States are predicted to decline the most. By contrast, 
the imports from Venezuela, Mexico, and Qatar are slightly higher in 2040 than that in 2030.

\section{Conclusions}

In this paper, a risk optimization model is proposed to identify the optimal diversification portfolio of China's and India's oil imports. The current oil import structure of each country implies that Middle Eastern countries maintain the dominant position among all of the suppliers to China and India. They account for almost half of the total oil imports to China and India. Suppliers with high country risk measures, such as South Sudan and Iraq, deteriorate the current oil supply security. Therefore, the effective diversification of crude oil imports plays an important role in energy security. The optimal results indicate that both China and India have a large room to improve the oil supply security. In order to reduce the oil supply risk, China should increase oil imports from the US and Kazakhstan and reduce imports from Saudi Arabia, Russia, and Angola by half. India should increase oil imports from the US and Russia and reduce crude oil imports from Iraq and Saudi Arabia.

Based on the forecasts of oil consumption and production, the optimal oil import strategy for China and India over the forecast period is proposed. In order to meet the fast-growing oil demand in China, crude oil imports from the United States and Kazakhstan are forecasted to increase by more than ten times by 2030 . Imports from many other countries should be doubled or tripled by 2040. China should continue to diversify the crude oil import sources and explore unconventional oil to make up for its impending domestic production decline after the peak oil production occurs. India needs a similar diversification strategy to ensure its oil supply security. Crude imports from all of the current suppliers will increase in 2030 and 2040. Africa and North America will play a more important role in India's oil supply security.

\section{Data Availability}

The statistics of China's top twenty oil import sources come from the General Administration of Customs of the People's Republic of China. India's oil imports' data are collected from the UN Comtrade Database. The forecasted crude oil consumption data for China and India come from BP Statistics (2019) and World Energy Outlook (2019) by the IEA. The forecasted oil production of China and India is based on World Energy Outlook (2019). The refining capacities are collected from World Energy Outlook (2019). The crude oil production is collected from World Energy Outlook (2019) under the New Policies Scenario and IEA website. We use the country composite risk rating and forecasts from the ICRG report.

\section{Disclosure}

The funders had no role in the design of the study, in the collection, analyses, or interpretation of the data, in the writing of the manuscript, or in the decision to publish the results.

\section{Conflicts of Interest}

The authors declare no conflicts of interest.

\section{Acknowledgments}

This research was supported by a grant from the National Social Science Fund of China (20BJY233).

\section{References}

[1] D. Von Hippel, T. Suzuki, J. H. Williams, T. Savage, and P. Hayes, "Energy security and sustainability in Northeast Asia," Energy Policy, vol. 39, no. 11, pp. 6719-6730, 2011.

[2] International Energy Agency (IEA), World Energy Outlook 2019, IEA Publications, Paris, France, 2019.

[3] P. Kraljic, "Purchasing must become supply management," Harvard Business Review, vol. 61, no. 5, pp. 109-117, 1983.

[4] G. C. K. Leung, "China's energy security: perception and reality," Energy Policy, vol. 39, no. 3, pp. 1330-1337, 2011.

[5] D. Yergin, "Ensuring energy security," Foreign Affairs, vol. 85, no. 2, pp. 69-82, 2006.

[6] V. Vivoda, "Diversification of oil import sources and energy security: a key strategy or an elusive objective?" Energy Policy, vol. 37, no. 11, pp. 4615-4623, 2009.

[7] S. Ghosh, "Future demand of petroleum products in India," Energy Policy, vol. 34, no. 15, pp. 2032-2037, 2006.

[8] W. D. Walls, "Petroleum refining industry in China," Energy Policy, vol. 38, no. 5, pp. 2110-2115, 2010.

[9] International Energy Agency (IEA), World Energy Outlook 2007 China and India Insight, IEA Publications, Paris, France, 2007.

[10] E. Gupta, "Oil vulnerability index of oil-importing countries," Energy Policy, vol. 36, no. 3, pp. 1195-1211, 2008.

[11] B. Kruyt, D. P. Van Vuuren, H. J. M. De Vries, and H. Groenenberg, "Indicators for energy security," Energy Policy, vol. 37, no. 6, pp. 2166-2181, 2009.

[12] C. Le Coq and E. Paltseva, "Measuring the security of external energy supply in the european union," Energy Policy, vol. 37, no. 11, pp. 4474-4481, 2009.

[13] N. Lefèvre, "Measuring the energy security implications of fossil fuel resource concentration," Energy Policy, vol. 38, no. 4, pp. 1635-1644, 2010.

[14] G. Cohen, F. Joutz, and P. Loungani, "Measuring energy security: trends in the diversification of oil and natural gas supplies," Energy Policy, vol. 39, no. 9, pp. 4860-4869, 2011.

[15] J. Jewell, A. Cherp, and K. Riahi, "Energy security under decarbonization scenarios: an assessment framework and evaluation under different technology and policy choices," Energy Policy, vol. 65, pp. 743-760, 2014. 
[16] J. Martchamadol and S. Kumar, "An aggregated energy security performance indicator," Applied Energy, vol. 103, pp. 653-670, 2013.

[17] E. Kiriyama and Y. Kajikawa, "A multilayered analysis of energy security research and the energy supply process," Applied Energy, vol. 123, pp. 415-423, 2014.

[18] B. W. Ang, "Lmdi decomposition approach: a guide for implementation," Energy Policy, vol. 86, pp. 233-238, 2015.

[19] M. Kashcheeva and K. K. Tsui, "Political oil import diversification by financial and commercial traders," Energy Policy, vol. 82, pp. 289-297, 2015.

[20] K. Narula and B. S. Reddy, "Three blind men and an elephant: the case of energy indices to measure energy security and energy sustainability,” Energy, vol. 80, pp. 148-158, 2015.

[21] M. Van Moerkerk and W. Crijns-Graus, "A comparison of oil supply risks in EU, US, Japan, China and India under different climate scenarios," Energy Policy, vol. 88, pp. 148-158, 2016.

[22] X. Sun, C. Liu, X. Chen, and J. Li, "Modeling systemic risk of crude oil imports: case of China's global oil supply chain," Energy, vol. 121, pp. 449-465, 2017.

[23] D. Fang, S. Shi, and Q. Yu, "Evaluation of sustainable energy security and an empirical analysis of China," Sustainability, vol. 10, no. 5, 2018.

[24] Y. Yang, S. Dong, F. Li et al., "Sino-Russian oil security: evolution and structure," IOP Conference Series: Earth and Environmental Science, vol. 381, Article ID 012100, 2019.

[25] H. Wan, X. Sun, T. Ling, and J. Li, "Modeling on oil-importing risk under risk correlation," in Proceedings of the 2009 International Joint Conference on Computational Sciences \& Optimization, Sanya, China, April 2009.

[26] S. H. Lesbirel and S. Sun, "Oil import diversification in the Asia-Pacific (1976-2014)," Journal of the Asia Pacific Economy, vol. 22, no. 4, pp. 1-5, 2017.

[27] L. Yao and Y. Chang, "Energy security in China: a quantitative analysis and policy implications," Energy Policy, vol. 67, pp. 595-604, 2014.

[28] W. Kang, "China's energy security: oil and gas," Energy Policy, vol. 73, pp. 4-11, 2014.

[29] J.-B. Geng and Q. Ji, "Multi-perspective analysis of China's energy supply security," Energy, vol. 64, pp. 541-550, 2014.

[30] H.-Y. Zhang, Q. Ji, and Y. Fan, "An evaluation framework for oil import security based on the supply chain with a case study focused on China," Energy Economics, vol. 38, pp. 87-95, 2013.

[31] F. Ge and Y. Fan, "Quantifying the risk to crude oil imports in China: an improved portfolio approach," Energy Economics, vol. 40, no. 2, pp. 72-80, 2013.

[32] C. Zhao and B. Chen, "China's oil security from the supply chain perspective: a review," Applied Energy, vol. 136, pp. 269-279, 2014.

[33] O. Odgaard and J. Delman, "China's energy security and its challenges towards 2035," Energy Policy, vol. 71, pp. 107-117, 2014.

[34] M. Mohsin, P. Zhou, N. Iqbal, and S. A. A. Shah, "Assessing oil supply security of South Asia,” Energy, vol. 155, pp. 438-447, 2018.

[35] M. Yuan, H. Zhang, B. Wang, L. Huang, K. Fang, and Y. Liang, "Downstream oil supply security in China: policy implications from quantifying the impact of oil import disruption," Energy Policy, vol. 136, 2020.

[36] W. Iqbala, A. Fatimaa, H. Yumei, Q. Abbas, and R. Iram, "Oil supply risk and affecting parameters associated with oil supplementation and disruption," Journal of Cleaner Production, vol. 255, 2020.
[37] N. Alkathiri, Y. Al-Rashed, T. K. Doshi, and F. H. Murphy, "“Asian premium" or "North Atlantic discount": does geographical diversification in oil trade always impose costs?" Energy Economics, vol. 66, pp. 411-420, 2017.

[38] X. Guo, C. Hao, and S. Niu, "Analysis of oil import risk and strategic petroleum reserve: the case of China," Sustainability, vol. 12 , no. 9 , p. $3723,2020$.

[39] R. Pode, "Addressing India's energy security and options for decreasing energy dependency," Renewable and Sustainable Energy Reviews, vol. 14, no. 9, pp. 3014-3022, 2010.

[40] A. Sharma, "India and energy security," Asian Affairs, vol. 38, no. 2, pp. 158-172, 2007.

[41] Kondepati, R., (2011). India's energy security: an overview. Available at SSRN 1953035.

[42] Q. Ming, H. Guo, and J. Zhao, "On the diversification of crude oil imports considering the price," Technology Economics, vol. 39, no. 1, pp. 74-81+88, 2020, in Chinese.

[43] Q. Ming and Y. Yang, "Towards a sustainable oil supply: a risk diversification model to measure oil security risk in Japan and South Korea," International Journal of Sustainable Development and Planning, vol. 13, no. 5, pp. 746-757, 2018.

[44] F. Holz, C. Von Hirschhausen, and C. Kemfert, "A strategic model of European gas supply (gasmod)," Energy Economics, vol. 30, no. 3, pp. 766-788, 2008.

[45] S. W. Salant, "Exhaustible resources and industrial structure: a Nash-Cournot approach to the world oil market," Journal of Political Economy, vol. 84, no. 5, pp. 1079-1093, 1976.

[46] H.-W. Sinn, "Common property resources, storage facilities and ownership structures: a Cournot model of the oil market," Economica, vol. 51, no. 203, pp. 235-252, 1984.

[47] A. M. Al-Sultan, "Alternative models of opec behavior," Journal of Energy Finance \& Development, vol. 18, no. 2, 1993.

[48] J. C. B. Cooper, "Price elasticity of demand for crude oil: estimates for 23 countries," OPEC Review, vol. 27, no. 1, pp. 1-8, 2003.

[49] L. Gang: Estimating Energy Demand Elasticities for Oecd Countries, A Dynamic Panel Data Approach, Discussion Papers, No. 373, 2004.

[50] BP, BP Statistical Review of World Energy 2019, BP, London, UK, 2019.

[51] N. N. Dalei, H. Roy, and A. Gupta, "Crude oil import of India from its major oil trade partner countries: an empirical evidence using panel data analysis," International Journal of Advanced Research and Development, vol. 2, no. 6, 2017.

[52] N. Ren, "Analysis and prospect of Indian oil market," International Petroleum Economy, vol. 27, no. 9, pp. 90-98, 2019.

[53] Y. Matsuo, A. Yanagisawa, and Y. Yamashita, "A global energy outlook to 2035 with strategic considerations for Asia and Middle East energy supply and demand interdependencies," Energy Strategy Reviews, vol. 2, no. 1, pp. 79-91, 2013.

[54] T. Toichi, "Energy security in Asia and Japanese policy," AsiaPacific Review, vol. 10, no. 1, pp. 44-51, 2003. 